https://helda.helsinki.fi

\title{
Enactive Perception and Fictional Worlds
}

\section{Polvinen, Merja Kristiina}

Palgrave Macmillan

2016

Polvinen, M K 2016 , Enactive Perception and Fictional Worlds . in P Garratt (ed.), The Cognitive Humanities : Embodied Mind in Literature and Culture . Palgrave Macmillan, London, pp. 19-34 .

http://hdl.handle.net/10138/306601

unspecified

acceptedVersion

Downloaded from Helda, University of Helsinki institutional repository.

This is an electronic reprint of the original article.

This reprint may differ from the original in pagination and typographic detail.

Please cite the original version. 


\section{Chapter 1}

\section{Enactive Perception and Fictional Worlds}

Merja Polvinen

Post-print version

Published in The Cognitive Humanities: Embodied Mind in Literature and Culture. Ed. by Peter Garratt. Palgrave, 2016.

\section{Introduction}

The study of spatiality in fiction has received a new boost with the advent of the cognitive approaches to literature. The focus in such research has been on understanding our imaginative engagement with fiction in terms of the means that human beings have developed for perceiving and understanding physical reality. However, as so often happens in the humanities, an overarching model may turn against itself at its margins. For cognitive literary approaches have not only connected literary imagining to our new understanding of general human capacities for cognition and perception, but they have also made the more farreaching suggestion that literary imagining basically follows the patterns of real-world cognition. In the case of specifically spatial imagination this would mean that readers' ways of experiencing fictional spaces would be understood as a special, illusion-framed version of our visual experiences of actual spaces. Such a view is built on the conceptualisation of literary imagining as a process where readers move their deictic centre into a fictional world in order to experience that world and its events from the 'inside'.

However, my argument in this chapter is that such a world-focused view obscures a central aspect of the experience of fiction: specifically, that it must be experienced as fiction - not as an illusion of reality. One of the areas where I believe the common spatial model 
turns out to be inadequate is the analysis of self-reflective fiction. It has been suggested many times that self-reflection throws readers out of the fictional world, ending or at least interrupting their perceptual (and emotional) immersion in the fiction. This makes intuitive sense and fits many of the theories of spatial perception that have so far guided our understanding of imagined spaces. It is also true that in much postmodern literature, selfreflection was mainly used for irony and ontological frame-breaking. However, loss of immersion in the fictional world is not the only function that self-reflection can have, and, particularly, a substantial part of fiction after postmodernism can be seen to be self-reflective for very different reasons and to aim for very different effects than its postmodernist forebears. ${ }^{1}$ Writers such as A. S. Byatt or Christopher Priest in the UK, as well as David Foster Wallace and Dave Eggers in the US, ask their readers to be both self-aware and engaged, and they build a reader position which assumes readers to be able to maintain these two states of mind at the same time - one experiencing the presence of a fictional space, characters and events, and another acutely aware of their imaginariness. Such texts question the in/out model of spatial imagination in fiction that we have relied on for so long.

Coinciding with these changes in the aims of literary self-reflection, a fundamental shift is taking place in the cognitive sciences about what human perception actually is and how it functions. The advent of the so-called 4E cognition - conceptualising human thought as embodied, emotional, enactive and extended - is challenging some of our deep-seated intuitions about what it means to see, or to experience an object as present. ${ }^{2}$ My suggestion in this chapter is that the 4E view of perception provides support for two arguments concerning fiction and our sense of space:

1. We do not fill in the details of an internal representation during reading, but that the experience of the presence of those details may, nevertheless, be as intense as our perception of reality. 
2. It is possible to perceive both the artwork and the fictional spaces it represents without see-sawing between two incompatible positions.

The first of these consequences of enactive perception has already received attention within literary studies and I discuss some of those findings below, but my focus in this chapter is on the second, and on its consequences for our understanding of self-aware fictionality.

To give detail to this theoretical discussion, I analyse in this chapter China Miéville’s conceptual thriller The City \& The City (2009), a novel which thematises and estranges our experience of space. Miéville crafts a genre-bending narrative around the idea of a politically divided urban community, where contact with the other side is strictly regulated. But unlike post-war Berlin with its clear division between East and West, the two cities of the novel are fragmented into intersecting spaces as small as a street or half a block. Furthermore, the system maintaining the division is conceptual and perceptual rather than physical: instead of encountering an actual wall, the inhabitants of both cities have learned since childhood to recognise areas and individuals as belonging either in their own city or in the other, and to actively block the other side from their own perceptual experiences. ${ }^{3}$ Thus the novel presents a fictional environment that differs from the norm by virtue of its perceptual accessibility and while the inhabitants of the two cities have to negotiate their urban space using cognitive capacities that are shared by the novel's readers, they do so in a way that presents the familiar action of seeing and moving in space in a manifestly unfamiliar light. ${ }^{4}$

What is most interesting to me in Miéville's novel is the way in which this estrangement of spatial perception is connected with a self-awareness of the conventions of fictional representation. The City \& The City asks its readers to perform a cognitive quickstep that involves not only imagining a new way of perceiving familiar spaces, but also an awareness that such a task is being presented to them via certain literary conventions, such as the red herrings of a detective story. Below I will analyse the first chapter of the novel to 
show how Miéville not only plays a magic trick on his readers’ perceptual systems, but also reveals exactly how the trick is done, and it is this doubled action of illusion and revelation on which the effect of the novel depends.

\section{Fictional Worlds and Deictic Shifts}

In recent decades, readers' perception of fictional space has been discussed mainly from two perspectives: possible worlds theory and experientiality. Possible worlds theory has its roots in the modal logic created by analytical philosophy to deal with problems thrown up by the formal semantics of counterfactual statements or expressions of necessity or possibility. ${ }^{5}$ Applying such a modal logic to the sentences in a work of fiction, possible worlds theory posits a system of reference where each statement 'proposed' by the fiction matches a possible world, and each of those has a different relationship to readers' actual world. These worlds include not only what Marie-Laure Ryan calls the 'textual actual world' - the fictional reality surrounding the text's characters - but also various 'epistemic' worlds formed around the beliefs and wishes of the characters, as well as the 'virtual' worlds projected by readers on the basis of their own hypotheses as to the twists and turns of plots. ${ }^{6}$

While possible worlds theory has its roots in the abstractions of analytical philosophy, as an approach to fiction it is often connected to the immediacy of readers' cognitiveemotional experience, in particular to the question of immersion or transport. Here the emphasis is not so much on modal logic, but on 'worldness' in the sense of 'lived imaginative experience'. ${ }^{7}$ Readers are understood to 'recenter' themselves in a world they construct under the guidance of the text out of 'internalized cognitive models, inferential mechanisms, reallife experience, and cultural knowledge, including knowledge derived from other texts' ${ }^{8}$

In the case of written fictions, making the connection between a fictional world and readers' experiential worlds is clearly dependent on language's ability to express 
spatiotemporal situatedness. Thus the analysis of immersion effects in written fiction is rooted in the analysis of deixis. In Story Logic, David Herman argues that 'to know who or what is being referred to at a given point in a narrative text is to have the ability build (or update) a mental model of where, within the storyworld, the thing referred to is located in time and space'. Thus 'narrative entails a process of cognitive mapping that assigns referents not merely a temporal but a spatiotemporal position in the storyworld'.${ }^{9}$ Herman proceeds to present a number of tools for analysing spatial presentation and the way it is processed by readers, the first and perhaps most central of which is the Deictic Shift Theory. DST is a conceptualisation of fictional space that bases itself partly on theories of fictional worlds and partly on cognitive linguistics. By decoding the linguistic cues built into narratives, DST suggests, readers not only imagine the relative positions of different items in the fictional space, but perform the imagined recentering of their own perspective within the fictional world, whether that perspective is tied to a specific fictional character or whether it is more like that of a floating 'witness'. Thus the metaphor of 'the reader getting inside of a story,' Erwin M. Segal suggests, is 'cognitively valid' in the sense that the reader interprets the information presented to her from an imagined deictic centre within a fictional world. ${ }^{10}$

It is clear however, that reliance on a model that renders imaginative actions in terms of real-world spaces naturalises the action of imagining to such an extent that we should be especially alert to what it brackets off as impossible or non-natural. This is also true in the case of DST, especially since it relies on a model of perception that is itself being challenged by developments such as the $4 \mathrm{E}$ model - developments that are changing what a phrase like 'cognitively valid' might itself mean. My suggestion is that because of their dependence on a model that naturalises fictional perception through older, pictorial theories of real-world perception, DST and other fictional worlds approaches are unable to discuss self-reflective phenomena in a fruitful way. 


\section{Fictionality, Self-Reflection and Imagined Spaces}

While the cognitive approaches to fictional worlds focus on readers' experience rather than on the modal logic of fictional worlds alone, they nevertheless rely on ontology in suggesting that those experiences essentially follow from the 'worldness' of a fictional world, rather than from its fictionality. That position has been criticised by Richard Walsh, who in The Rhetoric of Fictionality (2007) argues that the concept of fictional worlds is mistaken, as it assumes a system of ontology ruled by reference, whereas fictionality is a rhetorical quality ruled by relevance. 'Fictionality is neither a boundary between worlds, nor a frame dissociating the author from the discourse,' Walsh argues. Instead, it is 'a contextual assumption by the reader, prompted by the manifest information that the authorial discourse is offered as fiction. This contextual assumption is a preliminary move in the reader's effort to maximize relevance.' 11 Fictionality, therefore, becomes the primary element, the one that makes the construction of any kind of meaning out of the fiction possible, and rather than readers engaging with fiction in the naturalising way that erases fictionality from view, their 'awareness of its artifice is innate in any response whatsoever to fiction as such'. ${ }^{12}$ We therefore seem to have two incommensurable ways of understanding the cognitive processes involved in the reading of narrative fiction: where Walsh takes meaning-making to be dependent on readers approaching fiction as a constructed, communicative object, DST-based theories suggest that our perceptual intuitions are strong enough to hide the semiotic level and make the experience of fictional space fundamentally similar to the same as experiencing real space.

The problem of the incommensurability between fiction-oriented and world-oriented approaches to literature is brought to a head in self-reflective fiction. It seems to be a given in many of the cognitive approaches to fictional space that textual self-awareness is antithetical 
to the deictic shift and the consequent experience of immersion. Usually such effects are described in terms of movement across ontological levels, or of worlds seen as containers set one within the other. Mary Galbraith, for example, adopts the computer science terminology of 'POP' and 'PUSH' to describe readers' movements between different 'deictic planes' or 'fields'. The underlying assumption behind such terms is that readers are able to occupy such spaces only one at a time. 'At any moment of reading a narrative, a reader may attentionally occupy one of several deictic fields - for example, a character's subjectivity within the story world, or the author's wry commentary on some historical phenomenon'.13 Marie-Laure Ryan, whose work on immersion and interactivity in fiction tackles the issues of textual selfreflection directly, also claims that

[t]he cost of the metafictional stance is an ontological alienation of the reader from the fictional world. Insofar as it claims the reality of its reference world, fiction implies its own denial as fiction. By overtly recognizing the constructed, imaginary nature of the textual world, metafiction blocks recentereing and reclaims our native reality as ontological center. ${ }^{14}$

Thus the metaphor of fictional worlds here naturalises fiction as a series of spaces between which readers move. It is made clear that readers may move between immersion in and reflection on a fictional world during the process of reading a single work, but also that the two perspectives cannot exist for readers at the same time. This is because Ryan's theory of readerly experiences is built on a fundamental opposition between spatial perception and semiotic understanding. Literary texts cannot be both immersive and self-reflective 'because language behaves like holographic pictures: you cannot see the signs and the world at the same time. Readers and spectators must focus beyond the signs to witness the emergence of a three-dimensional lifelike reality'. ${ }^{15}$ Werner Wolf, in his extensive work on the phenomenon of the aesthetic illusion, builds a model that sets the experience of fiction on 'a scale between 
the - as a rule excluded - poles of total rational distance and complete (and predominantly emotional imaginative immersion'. ${ }^{16}$ The idea of a scale does not divide reason and imagination into separate ontological planes, but Wolf's model still maintains a spatially enforced division between the two experiences, as an increase in one quality would mean the decrease of the other, making the presence of self-reflection an inhibitor for the experience of immersion in a fictional world.

It is clear that such dichotomies have their roots in deeply intuitive spatial conceptualisations, but the problem is that they may lead us to dismissing some textual effects simply because those do not fit the appealing common-sense model. But looking past our own intuitions, we find that the perception of fictional worlds and the perception of their fictional and textual qualities only seem incommensurable actions if a) our model naturalises the action of imagining to the extent that only actions analogous to real-life spatiotemporality are possible in imaginative immersion, and b) if our model of perception itself is one that assumes perception to be an unthought, unmediated process. It is these two assumptions that I will interrogate below.

But before continuing with the theoretical debate, let me offer a brief analysis of the beginning of Miéville’s The City \& The City as a practical example of the issues involved. The novel opens with a classic crime-scene examination, presented to readers through the homodiegetic narration of Inspector Borlú:

I could not see the street or much of the estate. We were enclosed by dirt-coloured blocks, from windows out of which leaned vested men and women with morning hair and mugs of drink, eating breakfast and watching us. This open ground between the buildings had once been sculpted. It pitched like a golf course - a child's mimicking of geography. ${ }^{17}$ 
As Borlú examines the corpse of a murdered girl, familiarises himself with the scene and interviews the youngsters who have found the body, his perspective introduces readers to a world which seems to be familiar not only in terms of its physical details (low-income housing estates, skateboard parks and dumped mattresses) but also in terms of the clichés of a crime narrative (world-weary but incisive detective arrives at a crime scene, waits for the pathologist, interviews witnesses and deals with interfering news reporters). On the other hand, there are plenty of details to alert readers to the fact that this storyworld is not based on, say, contemporary Britain, the home of the novel's author and the detective genre he is indexing. Character names (Tyador Borlú, Lizbyet Corwi), references to unfamiliar places (Besźel, Lestov, GunterStrász) and cultural details (Comissars, Saint Warsha), as well as explicit mention of English not being the language spoken between the characters, all point away from the UK, but they do seem to be indicating a perfectly coherent and recognisable cultural space in Eastern Europe. Therefore, because the physical and cultural space includes so many recognisable items, and because the scene as a whole follows generic conventions, it feels instantly familiar, even as the details described are new.

However, on the final page of the first chapter something entirely different happens.

As I turned, I saw past the edges of the estate to the end of GunterStrász, between the dirty brick buildings. Trash moved in the wind. It might be anywhere. An elderly woman was walking slowly away from me in a shambling sway. She turned her head and looked at me. I was struck by her motion and met her eyes. I wondered if she wanted to tell me something. In my glance I took in her clothes, her way of walking, of holding herself, and looking.

With a hard start, I realised that she was not on GunterStrász at all, and that I should not have seen her. [...] When after some seconds I looked back up, unnoticing the old woman stepping heavily away, I looked carefully instead of at her in her 
foreign street at the facades of the nearby and local GunterStrász, that depressed zone. $^{18}$

This final paragraph, as well as the opening of Chapter Two where the issue of 'unseeing' and the difference between 'local' and 'elsewhere' are given more detail, brings surprises that cannot be incorporated into the carefully constructed picture of a realistic crime mystery set in Eastern Europe. Having something visible that should not be seen, and having a foreign street right in the middle of a known city, are conceptual oddities that disturb the experience of familiarity that readers' have already settled into. Furthermore, a retrospective view of the opening chapter shows how Miéville has, in fact, very consciously played a trick on the spatial imaginations of his readers by making them draw heavily on their deictic intuitions to fashion an impression of a detailed scene. When Borlú says at the opening that he 'could not see the street or much of the estate', it is initially easy to assume he is referring to sightlines blocked by trees or buildings, but in retrospect he is more likely talking about an area of his visual field that is rendered inaccessible by the politics of his bizarre urban environment. For readers, the resulting sense of a scene dissolving and reordering itself is analogous to situations where a literary work purposefully exposes racial or gender-based prejudices by allowing a stereotypical view of a character to form and solidify before revealing that character's minority status. ${ }^{19}$

The opening chapter of Miéville’s novel thus purposefully performs a self-reflective trick that invites readers to become aware of the processes by which they imagine fictional spaces. The spatial double-take creates for the rest of the novel a sense of combined immersion and estrangement which is not only typical of speculative fiction, ${ }^{20}$ but which in this particular case also strengthens the novel's theme of maintaining and/or crossing physical, perceptual and conceptual borders. Furthermore, the effect is underlined by the selfconscious use of and reference to detective-story conventions as well as to philosophical and 
literary theoretical discussions of the problem of representation - for example, the use of phrases such as 'the mise-en-crime' and the description in the very first paragraph of the parkland as 'a child's mimicking of geography'. ${ }^{21}$

What is most interesting to me here is the way in which the engagement of readers' spatial perception is connected to an awareness of the conventions of fictional representations. For at the same time as he draws readers' attention to the process of literary imagining, Miéville is expecting readers to be able to fully experience the first-person narrator's strange perceptual world. The process of self-reflection here is so tightly wrapped up with imagined perceptions that describing them as two separate positions that readers alternate between fails to capture the experience. The question then becomes one of finding a way of conceptualising human perception in such a way that imaginative engagement and self-reflection do not shut each other out - a model that is able to retain the semiotic or fiction-oriented awareness as part of the experience even when imaginative spatial immersion is taking place.

\section{Literary Imagining as Enactive Perception}

One of the risks associated with the DST is the ease with which it leads us to the so-called 'snapshot conception' of what seeing is like: that our eyes and brains together create a representation of a unified visual field. The snapshot conception underlies for example Ernst Mach’s famous 1886 drawing of the visual field, but it was overturned by twentieth-century research showing how visual perception, instead of registering a full picture of the space in view all at once, actually consists of fragmentary information gained from sequential focusing on various details through the eyes' saccadic movements. In addition, our visual accuracy is hounded by actual physical blind spots, change blindness or inattentional blindess (e.g. the case of the invisible gorilla), and visual experiences of things we do not strictly 
speaking see (e.g. the Kanizsa triangle). ${ }^{22}$ As a result, the seamless, detailed visual field has been deemed an illusion - in the sense of it being a representation produced in our brains on the basis of the fragments provided by our eyes.

But even though the snapshot conception has been overturned as such, most of our thinking about visual perception - and about imagination - is still organised around the idea that visual experience consists of a coherent picture of the world; only that now such a picture is a representation our brains have constructed. It is this dependence on internal representations that the theory of enactive perception seeks to overthrow. Spearheaded by the philosopher Alva Noë, the enactive view understands perception as a form of direct contact with the world:

$[\mathrm{M}] \mathrm{y}$ sense of the presence of the detail in the room before me consists not in the fact that I represent it all in my consciousness in the way a picture might - all the detail spread out at once in sharp focus and high resolution. It does not even seem as if the detail is present in my mind that way. It seems as if the detail is present in the world, out there, before me and around me. The detail shows up not as 'represented in my mind', but as available to me. ${ }^{23}$

Such 'availability' or accessibility of objects and spaces is in the enactive paradigm dependent on our own physical action in relation to the world. ${ }^{24}$ Rather than being a mere receptive medium, human perception is a sensorimotor skill whereby the embodied action of the perceiver makes the world available to experience. Such action includes moving our eyes, our head, or even the whole body to bring out new aspects of the object being looked at. ${ }^{25}$ Once the amount of action we undertake during even the most basic visual perception is factored in, our understanding of perception should, in fact, move away from 'a quasiphotographic or optical-projective' analogy, and instead 'we should think of perceiving in terms of touching' - as an active exploration of the world rather than passive reception of 
data from it. ${ }^{26}$ Objects that have become accessible in the sense described by the enactive approach can be said to be present in perception, whether they are strictly speaking seen or not. Thus, through our skillful access to the world, we have a perceptual sense that, for example, the backside of a tomato is there, present in our experience, even when it is hidden from view.

Cognitive literary scholarship has already made note of the enactive model of perception and of how useful it can be for conceptualising the way in which imagined spaces can convey a sense of presence and immersive detail. If we think, as Marco Caracciolo does, of the literary imagination as 'enacting seeing, not seeing a picture-like mental image', we can move away from the need to conceptualise life-like imagining as a process of filling in perceptual detail to an otherwise unnaturally empty picture. Instead of such overly detailed representations, the experience of fictional spaces can be built on a theory of accessibility, so that 'we experience the space constructed by [literary descriptions] because we know that we could, at least in principle, rearrange the settings in a coherent and fully determinate mental image'. ${ }^{27}$ The fact that we do not actually undertake that task except on rare occasions does not undermine the sense of access created by the text. In fact, as Anežka Kuzmičová has shown, descriptive details or 'presence ques' must be used sparingly if a text wishes to convey a sense of verisimilarity. ${ }^{28}$

In addition to the clear benefits of the enactive approach for dealing with the thorny issues of verisimilarity, it is also useful in approaching the debate between the semiotic and world approaches to fiction and self-reflection. What exactly is being experienced as present and accessible to us: the crafted, communicative fiction, or the world it seems to represent or both? I suggest that in order to understand self-reflection in fiction we need to turn our focus away from the perceptual experience of fictional objects and towards the fact that the action of perception is also of the artistic object itself - the words arranged into a fictional 
narrative. If, as Caracciolo suggests, reading fiction is an 'active exploration of a non-actual environment', the non-actuality of that environment is one of the qualities that we have to negotiate. ${ }^{29}$ Thus the actions we engage in while reading fiction are based not only on our sensory-motor skills as they are engaged by world-like qualities, but also on our learned understanding of fictional representation, and of its differences from both real-world perceptions and of other, non-fictional forms of representation.

What makes the enactive view useful for this work on self-reflection in fiction is an aspect of Noë's thinking that has not received much attention from literary scholars so far: that is, the duality of perceptual experience. For not only is action part and parcel of our perceptual experiences, but so is the fact that we have learned the actions that make the world present to us. Thus '[p]erception is an activity that requires the exercise of knowledge of the way action affects sensory stimulation'. ${ }^{30}$ Perception therefore consists of two interconnected and simultaneous aspects: a) what 'experience presents the world as being' and b) 'the way the world is presented in experience'. ${ }^{31}$ Noë's example for this duality is the visual perception of a plate hanging on a wall. Looked at from an angle, the plate appears elliptical, while at the same time our knowledge of the appearances of circular objects allows us to experience it as a round plate. These two aspects, or what Noë calls the 'non-constancies' and ‘constancies' of perception are present simultaneously. ${ }^{32}$

Thus, while the perceiver learns to negotiate the world by understanding that the way things look (perceptual non-constancies) is not the same as how they are (perceptual constancies), her experience continues to include both aspects. If we now continue to follow an analogy between the Noë's perceptual access and the experience of fiction, we must also factor in such a 'full-blooded duality of perceptual experience', ${ }^{33}$ and note that our sense of a high-resolution perception is dependent on our understanding of the significance of our own enactive processing of the fiction as fiction. Connecting back to Walsh's arguments 
concerning the priority of the semiotic in our encounters with fiction, we could then say that the rhetoric of fictionality involves a semantic skill set required for perceiving fictional environments, one that we need to use in order to 'see' that world in the first place. Even selfconscious use of those skills, however, does not mean that the 'worldness' of fictions disappears from view. Fictionality in representation, I suggest, sets us the task of experiencing both the world being represented and the constancies of fictionality.

One of the obstacles in trying to think about fictionality and perception in these terms is the intuition revealed in Ryan's and Wolfe's analogies for self-reflection: that having two such different perspectives at the same time should be impossible, just like it is impossible to observe a space both from the inside and the outside, or both the duck and the rabbit in Wittgenstein's much-cited image. But these analogies lead us down a false trail. As Noë notes, the task of flipping between one animal and the other in the duck-rabbit image is an attentional task, not a perceptual one, and the duality of perception is therefore not analogous with first seeing the duck and then seeing the rabbit. Instead, it is like seeing either animal and seeing the drawn lines that represent it. 'Seeing the duck, and the lines on paper, is not a matter of dividing attention between them; it is simply a matter of having skillful access to them both at once'. ${ }^{34}$ Similarly, self-reflective fiction may work on our sense of access rather than on our attention, and as such does not require the kind of flipping that is often taken as the only way our perceptual and imaginative capacities are able to deal with self-reflection in fiction.

\section{Conclusion}

'Awareness extends to that to which we have access and does not require divided attention,' Noë argues. ${ }^{35}$ Thus it is possible for Miéville’s readers to experience how Borlú, navigating his way through a 'cross-hatched' area of the two cities, 'stop-started, excusing myself to 
citizens and local tourists, unseeing others with care', ${ }^{36}$ and at the same time be aware of the techniques of textual representation that create that effect in her. From the enactive perspective, reading fiction is a way of encountering how things appear to be (life-like) by making contact with how things are (fictional). While Deictic Shift Theory and the spatial metaphors of entering and exiting worlds seem to match many of our intuitions about the ontological levels encountered during reading, they are misleading when it comes to understanding the fictionality of fictions, and particularly unhelpful for describing the experience of experimental fictional environments, such as those generated by self-reflective fiction. Instead, the sensation of encountering a fictional world may be better explained through the enactive conceptualisation of having sensory access to it, with the perception forming in cooperation between the object and the actions of the embodied mind encountering it - actions which include the meaning-making based on our skill as users of fictional narratives.

\section{References}

Ameel, Lieven and Sirpa Tani. 'Everyday Aesthetics in Action: Parkour Eyes and the Beauty of Concrete Walls,' Emotion, Space and Society 5 (2012), 164-173.

Bortolussi, Marisa and Peter Dixon. 'Transport: Challenges to the Metaphor,' The Oxford Handbook of Cognitive Literary Studies, ed. Lisa Zunshine (Oxford: Oxford University Press, 2015), 523-540.

Caracciolo, Marco. 'The Reader's Virtual Body: Narrative Space and Its Reconstruction,' Storyworlds 3 (2011), 117-138. 
Caracciolo, Marco. 'Blind Reading: Toward an Enactivist Theory of the Reader's Imagination,' Stories and Minds: Cognitive Approaches to Literary Narrative, ed. by Lars Bernaerts et al. (Lincoln and London: University of Nebraska Press, 2013), 81-105.

Doležel, Lubomir. Heterocosmica: Fiction and Possible Worlds (Baltimore: Johns Hopkins University Press, 1998).

Esrock, Ellen J. 'Embodying Literature,' Journal of Consciousness Studies 11, no. 5-6 (2004), 79-89.

Freedman, Carl. 'From Genre to Political Economy: Miéville’s The City \& The City and Uneven Development,' Centennial Review 13, no. 2 (2013), 13-30.

Galbraith, Mary. 'Deictic Shift Theory and the Poetics of Involvement in Narrative,' Deixis in Narrative: A Cognitive Science Perspective, ed. Judith F. Duchan, Gail A. Bruder and Lynne E. Hewitt (Hillsdale, NJ and Hove: Lawrence Erlbaum, 1995), 19-59.

Gerrig, Richard J. Experiencing Narrative Worlds: On the Psychological Activities of Reading (Boulder, CO: Westview Press, 1998).

Herman, David. Story Logic: Problems and Possibilities of Narrative (Lincoln and London: University of Nebraska Press, 2004). 
Huber, Irmtraud. Literature after Postmodernism: Reconstructive Fantasies (Houndmills: Palgrave Macmillan, 2014).

Kuzmičová, Anežka. 'Presence in the Reading of Literary Narrative: A Case for Motor Enactment,' Semiotica 189, no. 1/4 (2012), 23-48.

McHale, Brian. 'Science Fiction, or, the Most Typical Genre in World Literature,' Genre and Interpretation, ed. Pirjo Lyytikäinen, Tintti Klapuri and Minna Maijala (Helsinki: University of Helsinki, 2010), 11-27.

Margolin, Uri. 'Cognitive Science, the Thinking Mind, and Literary Narrative,' Narrative Theory and the Cognitive Sciences, ed. David Herman (Stanford, CA: CSLI, 2003), 271-294.

Menary, Richard. 'Introduction to the Special Issue on 4E Cognition,' Phenomenology and the Cognitive Sciences 9, no. 4 (2010), 459-463.

Miéville, China. The City \& The City (London: Pan Macmillan, 2009).

Noë, Alva. Action in Perception (Cambridge MA and London: MIT Press, 2004).

Noë, Alva. 'Understanding Action in Perception: Reply to Hickerson and Keijzer,' Philosophical Psychology 20, no. 4 (2007), 531-538.

Noë, Alva, Varieties of Presence (Cambridge, MA and London: Harvard University Press, 2012). 
O’Regan, Kevin J. and Alva Noë. 'A Sensorimotor Account of Vision and Visual Consciousness,' Behavioral and Brain Sciences 24 (2001), 939-1031.

Pavel, Thomas. Fictional Worlds (Cambridge, MA: Harvard University Press, 1986).

Ronen, Ruth. Possible Worlds in Literary Theory (Cambridge: Cambridge University Press, 1994).

Ryan, Marie-Laure. Narrative as Virtual Reality: Immersion and Interactivity in Literature and Electronic Media (Baltimore: Johns Hopkins University Press, 2001).

Ryan, Marie-Laure. 'Possible Worlds,' The Living Handbook of Narratology, ed. Peter Hühn et al. (Hamburg: Hamburg University, 2013), http://www.lhn.uni-hamburg.de/article/ possible-worlds [accessed 31 July 2014]

Ryan, Marie-Laure. Possible Worlds, Artificial Intelligence and Narrative Theory (Bloomington: University of Indiana Press, 1991).

Segal, Erwin M. 'Narrative Comprehension and the Role of Deictic Shift Theory,' Deixis in Narrative: A Cognitive Science Perspective, ed. Judith F. Duchan, Gail A. Bruder and Lynne E. Hewitt (Hillsdale, NJ and Hove: Lawrence Erlbaum, 1995), 3-17. 
Sinding, Michael. 'Storyworld Metaphors in Swift's Satire,' Beyond Cognitive Metaphor

Theory: Perspectives on Literary Metaphor, ed. Monika Fludernik (New York and London: Routledge, 2011), 239-257.

Stewart, John, Oliver Gapenne and Ezequiel A. Di Paolo, eds. Enaction: Toward a New Paradigm for Cognitive Science (Cambridge, MA and London: MIT Press, 2010).

Walsh, Richard. The Rhetoric of Fictionality (Columbus, OH: Ohio State University Press, 2007).

Wolf, Werner. 'Aesthetic Illusion,' Immersion and Distance: Aesthetic Illusion in Literature and Other Media, ed. Werner Wolf, Walter Bernhart and Andreas Mahler (Amsterdam and New York: Rodopi, 2013), 1-63.

\footnotetext{
${ }^{1}$ See e.g. Irmtraud Huber, Literature after Postmodernism: Reconstructive Fantasies (Houndmills: Palgrave Macmillan, 2014), 6-11.

${ }^{2}$ Menary, Richard, 'Introduction to the Special Issue on 4E Cognition,' Phenomenology and the Cognitive Sciences 9, no. 4 (2010), 459-463; and John Stewart, Oliver Gapenne and Ezequiel A. Di Paolo, eds. Enaction: Toward a New Paradigm for Cognitive Science (Cambridge, MA and London: MIT Press, 2010).

${ }^{3}$ Barbara Dancygier's chapter in this volume provides a further perspective on such boundary metaphors and the ways in which authors can manipulate shifts of viewpoint and readers' embodied responses. The 'Wall' in A Midsummernight's Dream that Dancygier discusses is present as an embodied human character, whereas in Miéville's novel the boundary has become completely imaginary, even while its presence remains in the characters' perceptual experience.

${ }^{4}$ In some senses the characters' vision of their urban landscape resembles that of parkour practitioners who view their environment through 'parkour vision' that renders accessible routes that are invisible (impossible) to other city-dwellers; see Lieven Ameel and Sirpa Tani, 'Everyday Aesthetics in Action: Parkour Eyes and the Beauty of Concrete Walls,' Emotion, Space and Society 5 (2012), 164-173: 165. For a view of how conceptual metaphors organise
} 
storyworlds see Michael Sinding, 'Storyworld Metaphors in Swift's Satire,' Beyond Cognitive Metaphor Theory: Perspectives on Literary Metaphor, ed. Monika Fludernik (New York and London: Routledge, 2011), 239-257. For analysis of the ideological underpinnings of Miéville’s novel, see Carl Freedman, 'From Genre to Political Economy: Miéville’s The City \& The City and Uneven Development,' Centennial Review 13, no. 2 (2013), 13-30. ${ }^{5}$ See e.g. Thomas Pavel, Fictional Worlds (Cambridge, MA: Harvard University Press, 1986), Marie-Laure Ryan, Possible Worlds, Artificial Intelligence and Narrative Theory (Bloomington: University of Indiana Press, 1991), Ruth Ronen, Possible Worlds in Literary Theory (Cambridge: Cambridge University Press, 1994) and Lubomir Doležel,

Heterocosmica: Fiction and Possible Worlds (Baltimore: Johns Hopkins University Press, 1998). For an overview of the history of possible worlds theory see Marie-Laure Ryan, 'Possible Worlds,' The Living Handbook of Narratology, ed. Peter Hühn et al. (Hamburg: Hamburg University, 2013), http://www.lhn.uni-hamburg.de/article/ possible-worlds [accessed 31 July 2014].

${ }^{6}$ Ryan, Possible Worlds, 109-147.

${ }^{7}$ Ryan, 'Possible Worlds,' no pagination.

${ }^{8}$ Ryan, Possible Worlds, 91. For immersion and transport see also Marie-Laure Ryan, Narrative as Virtual Reality: Immersion and Interactivity in Literature and Electronic Media (Baltimore: Johns Hopkins University Press, 2001), 89-163; and Richard J. Gerrig, Experiencing Narrative Worlds: On the Psychological Activities of Reading (Boulder, CO: Westview Press, 1998), 2-17. For a critique of some of the empirical studies building on the idea of transport, see Marisa Bortolussi and Peter Dixon, 'Transport: Challenges to the Metaphor,' The Oxford Handbook of Cognitive Literary Studies, ed. Lisa Zunshine (Oxford: Oxford University Press, 2015), 523-540.

${ }^{9}$ David Herman, Story Logic: Problems and Possibilities of Narrative (Lincoln and London: University of Nebraska Press, 2004), 270; 297, emphasis in the original.

${ }^{10}$ Erwin M. Segal, 'Narrative Comprehension and the Role of Deictic Shift Theory,' Deixis in Narrative: A Cognitive Science Perspective, ed. Judith F. Duchan, Gail A. Bruder and Lynne E. Hewitt (Hillsdale, NJ and Hove: Lawrence Erlbaum, 1995), 3-17: 15.

${ }^{11}$ Walsh, Richard. The Rhetoric of Fictionality (Columbus, OH: Ohio State University Press, 2007), 36.

${ }^{12}$ Walsh, Rhetoric, 172.

${ }^{13}$ Mary Galbraith, 'Deictic Shift Theory and the Poetics of Involvement in Narrative,' Deixis in Narrative: A Cognitive Science Perspective, ed. Judith F. Duchan, Gail A. Bruder and Lynne E. Hewitt (Hillsdale, NJ and Hove: Lawrence Erlbaum, 1995), 19-59: 47; 49, emphasis added.

${ }^{14}$ Ryan, Narrative, 284.

${ }^{15}$ Ryan, Narrative, 284.

${ }^{16}$ Werner Wolf, 'Aesthetic Illusion,' Immersion and Distance: Aesthetic Illusion in

Literature and Other Media, ed. Werner Wolf, Walter Bernhart and Andreas Mahler (Amsterdam and New York: Rodopi, 2013), 1-63: 16-17, emphasis deleted.

${ }^{17}$ China Miéville, The City \& The City (London: Pan Macmillan, 2009), 3.

${ }^{18}$ Miéville, City, 14.

${ }^{19}$ Uri Margolin discusses similar phenomena in terms of 'frame blocking' in 'Cognitive Science, the Thinking Mind, and Literary Narrative,' Narrative Theory and the Cognitive Sciences, ed. David Herman (Stanford, CA: CSLI, 2003), 271-294: 276-277.

${ }^{20}$ For the interplay of estrangement and naturalisation in SF, see e.g. Brian McHale, 'Science Fiction, or, the Most Typical Genre in World Literature,' Genre and Interpretation, ed. Pirjo 
Lyytikäinen, Tintti Klapuri and Minna Maijala (Helsinki: University of Helsinki, 2010), 1127.

${ }^{21}$ Miéville, City, 4, 3.

${ }^{22}$ For the invisible gorilla and the Kaniza triangle, see e.g. Alva Noë, Action in Perception (Cambridge MA and London: MIT Press, 2004), 52-53, 60-62.

${ }^{23}$ Alva Noë Varieties of Presence (Cambridge, MA and London: Harvard University Press, 2012), 19.

${ }^{24}$ For a different sense of accessibility in philosophy and possible worlds theory, see Ronen, Possible Worlds, 61-71. Philosophical accessibility is a characteristic of a world's logical possibility in relation to some other world, rather than a question of sensory access.

${ }^{25}$ Kevin J. O’Regan and Alva Noë, 'A Sensorimotor Account of Vision and Visual Consciousness,' Behavioral and Brain Sciences 24 (2001), 939-1031.

${ }^{26}$ Noë, Varieties, 70.

${ }^{27}$ Marco Caracciolo, 'Blind Reading: Toward an Enactivist Theory of the Reader's Imagination,' Stories and Minds: Cognitive Approaches to Literary Narrative, ed. by Lars Bernaerts et al. (Lincoln and London: University of Nebraska Press, 2013), 81-105: 89; and 'The Reader's Virtual Body: Narrative Space and Its Reconstruction,' Storyworlds 3 (2011), 117-138: 133. On non-visual sensory experiences in literature, see e.g. Ellen J. Esrock, 'Embodying Literature,' Journal of Consciousness Studies 11, no. 5-6 (2004), 79-89.

${ }^{28}$ Kuzmičová, Anežka. 'Presence in the Reading of Literary Narrative: A Case for Motor Enactment,' Semiotica 189, no. 1/4 (2012), 23-48: 43, emphasis in the original.

${ }^{29}$ Caracciolo, 'Blind Reading,' 81.

${ }^{30}$ Alva Noë, 'Understanding Action in Perception: Reply to Hickerson and Keijzer,' Philosophical Psychology 20, no. 4 (2007), 531-538: 532, emphasis added.

${ }^{31}$ Noë, Action, 163, emphasis in the original.

${ }^{32}$ Noë, Varieties, 45; and Action, 163.

${ }^{33}$ Noë, Varieties, 52.

${ }^{34}$ Noë, Varieties, 22.

${ }^{35}$ Noë, Varieties, 22.

${ }^{36}$ Miéville, City, 16. 